\title{
Comparison of the gravimetric sampling and impedance methods for measuring soil moisture content
}

\author{
Michal Allman, Martin Jankovský*, Zuzana Allmanová \\ and Valéria Messingerová
}

\begin{abstract}
Allman, M., Jankovský, M., Allmanová, Z., Messingerová, V. 2015. Comparison of the gravimetric sampling and impedance methods for measuring soil moisture content. Forestry Studies | Metsanduslikud Uurimused 62, 14-25. ISSN 1406-9954. Journal homepage: http://mi.emu.ee/forestry.studies
\end{abstract}

\begin{abstract}
This paper was focused on determining whether gravimetric sampling and impedance method of measuring soil moisture content provided different results and if they did, what was the size of the differences between particular methods on rendzinas and cambisols. The means of moisture content should be equal when using both methods on similar spots. During the research, an Eijkelkamp Penetrologger penetrometer equipped with impedance probes and gravimetric sampling cylinders from Eijkelkamp were used. The samples were taken from the undisturbed stand, ruts, and the centre of the skid trail. The impedance probes were inserted six centimetres deep into the soil. Soil samples were taken from similar depth in order to calculate the moisture content through the gravimetric method. 138 measurements were carried out for each method. The minimal difference of moisture contents measured by individual methods was $0.01 \%$, maximal difference was $22.06 \%$, and on average it was $7.42 \%$. Oneway ANOVA was used for first stage analysis of the statistical sample. It proved that the differences between measurements were statistically significant in two out of three considered stands. Tukey's HSD test was used to identify which data groups contributed to refuting the aforementioned hypothesis. The test showed that in one stand all relevant pairs of data were significantly different, while in the other stand only data pairs from the ruts were significantly different. The calibration method provided by the producers did not refine the accuracy of the impedance probes sufficiently and different calibration procedures have to be used.
\end{abstract}

Key words: forest harvesting erosion, impedance probe, cambisol, rendzina, Kopecky cylinders.

Authors' address: Department of Forest Harvesting, Logistics and Ameliorations, Faculty of Forestry, Technical University in Zvolen, T.G. Masaryka 24, 96053 Zvolen, Slovakia, *e-mail: martin.jankovsky@tuzvo.sk

\section{Introduction}

Soil moisture content is one of the most important factors when considering deploying ground based machines in forest stands. Negative effects, mostly caused by inadequate selection of forest harvesting technology or machines, show in rutting and subsequent forest harvesting erosion (Ferenčík, DOI: 10.1515/fsmu-2015-0002

(C) 2015 Estonian University of Life Sciences. All rights reserved 2011a; Ferenčík, 2011b). When using ground based forest harvesting machines, the machine presses its tyres into the soil surface and creates ruts. Their depth and width depends on the type of tyre, the weight of the load and the machine itself, the moisture content of soil, the state of soil surface and the number of passages (Gerasimov \& Katarov, 2010). The disturbance of soil 
profile is usually defined as mixing or removal of the humus layer or the soil itself. This causes change of soil's physical, chemical and biological properties (Flinn \& Bales, 1990). Disturbance of the soil profile causes change of soil's bulk density, which affects the soil characteristics (Rab, 1994), reduces and redistributes the organic material (Anderson et al., 1992; Ryan et al., 1992), modifies the macroporosity and hydraulic conductivity of soil (Rab, 1994). Loss of top soil horizons can therefore reduce tree growth (Farrish, 1990). Minimizing forest harvesting erosion is vital for keeping stable ecosystems. For an efficient prevention, it is necessary to restrict the uncontrolled machine traffic in forest stands by using preventive methods (Sklenar, 2008).

All operations connected with forest harvesting cause disturbances to the top layer of soil (Nemestothy, 2009). To be able to manage forests in a sustainable way, it is necessary to ensure long-term protection of forest soils (Uhl et al., 2003). Soil moisture content has substantial effects on soil's carrying capacity (Poršinsky et al., 2006). Rab et al. (2005) found that the critical moisture content, at which maximal compaction occurs, is in a range of 39 to $49.2 \%$ for top soil horizons and in a range of 24 to $48.5 \%$ for lower horizons. In general, forest harvesting frequently takes place in unsuitable climatic conditions. The seasonal effects and climatic phenomena (precipitation, temperature, and underground water levels) affect soil moisture content, thus affecting its carrying capacity (Šušnjar et al., 2006).

To ensure minimization of top soil layer disturbance during the forest harvesting it is necessary to accurately measure the moisture content of soil as a factor, which significantly affects the susceptibility of soil to such disturbance, and only after evaluating the moisture conditions make the decision about deploying ground based machinery in the forest stands. In order to make a justified decision, the forest managers need to accurately measure the soil moisture content.
There are several methods of measuring soil moisture content. The standard method is gravimetric sampling, which requires having information on the weight of the sample before and after drying and subsequent calculation of moisture content (Kaleita et al., 2005; Cosh et al., 2005).

One of the possibilities is to use the impedance method. This method requires use of specific equipment capable of measuring the soil impedance - impedance probes attached to a computational unit, e.g. penetrometer. The impedance probe measures volumetric soil moisture content, by responding to changes in apparent dielectric constant of moist soil (Roth et al., 1992). Processing unit converts the changes in the dielectric constant (in $\mathrm{mV}$ ) to moisture content through formula (1), because it was found by Whalley (1993) and White et al. (1994) that soil moisture content is proportional to the refractive index of the soil. To be able to compute the soil moisture content precisely, the parameters of the regression line have to be calculated from calibration on gravimetric samples.

$\sqrt{\mathcal{E}}=a_{0}+a_{1} \times \theta$

$\sqrt{\varepsilon}$ - dielectric constant, $a_{0}$ - coefficient for dry soil, $a_{1}$ - coefficient for moist soil, $\theta$ moisture content of soil.

Several other formulas exist for calculation of soil moisture content from the soil impedance (Fares et al., 2011). Using this method is popular, because the measurements are easy to carry out and the results are available instantaneously and in digital form.

Our goal was to identify whether using the impedance method would be a suitable substitute for the gravimetric sampling method. The aim was to determine whether there are any differences between the moisture content measured by gravimetric sampling and by the impedance probes, calibrated according to the manufacturer's specifications. If there are any differences between the results obtained by 
each method, we wanted to find whether the size of these differences is negligible or the impedance probes need to be calibrated further. We determined the significance of possible inaccuracies of the impedance method by statistically evaluating the results provided by individual methods on rendzinas and cambisols. Measuring soil moisture content accurately is vital for the forest managers, because even a slight difference between the measured soil moisture content and actual soil moisture content can have massive negative impacts on the ecosystem. These negative impacts can occur when the soil moisture content is near the Atterberg plasticity limits, which determine the threshold of solid/plastic state of soil. If the decision about harvesting in these conditions is based on an inaccurate measurement of soil moisture content, the forest harvesting machines would cause irreparable damage to forest soils (plastic deformation) and their passages would result in the formation of deep ruts, rendering subsequent activities inefficient and in numerous cases infeasible (Sever \& Horvat, 1981). Gravimetric sampling is considered the most accurate method currently used in moisture content determination. However, conducting a survey using the gravimetric sampling method whenever the forest managers are uncertain about deploying ground based machines in the forest stands would be labour intensive, time consuming, costly, and it would not be effective, because moisture content is a dynamic process and it takes more than 24 hours to obtain results from gravimetric sampling, rendering them obsolete in many cases. It would be easier if forest managers used a different, but sufficiently accurate method, for example the impedance method.

\section{Material and Methods}

\section{Study area}

The study was conducted in three stands in Slovakia and the Czech Republic. The total area of the stands was 21.13 ha $(211,300$ $\mathrm{m}^{2}$ ). Detailed characteristics of the forest stands are shown in Table 1. Both tracked and wheeled cut-to-length (CTL) machines operated in the stands. Slovak National Forestry Centre provided a GIS database, which enabled us to identify the soil types in the individual forest stands and the geographical coordinates of the forest stands.

Stands no. 187c20 and 188 had similar natural conditions, rendzina soils, and were a part of the same forest district. In both cases, the harvesting squad carried out a thinning. Stand no. 805j13 was situated in forest district Konopište (Czech Republic) and the soil type was cambisol. The harvesting squad carried out a clear cut in this stand.

\section{Data collection}

An Eijkelkamp Penetrologger penetrometer, equipped with an impedance probe (Theta Probe) (Manufacturer: Eijkelkamp Agrisearch Equipment, Netherlands; purchased from: Ekotechnika, s.r.o., Czech Republic, year of purchase: 2010) was used to conduct the soil impedance measurements throughout the study. Technical specification of the Theta probe is shown in Table 2. The probes were calibrated according to the specifications of the manufacturer. The calibration process is available in Appendix 1 of the Eijkelkamp ML3 ThetaProbe user manual (Eijkelkamp, 2013). A soil sample from each stand was collected prior to main measurements to provide calibration data. Before we inserted the impedance probe into the soil we removed the litter from the surface, as this would affect the outcome of the measurements. The impedance probe was inserted into the soil vertically, so that the whole prongs were covered by soil (approximately $6 \mathrm{~cm}$ deep). The voltage measurement was recorded, the probe was removed and a soil sample was taken from a nearby spot.

Kopecky cylinders are standard instruments used for soil sampling. The set consists of multiple sealable sampling cylinders 
Table 1. Basic characteristics of stands where the research took place. SM - Picea abies, BO - Pinus sylvestris, SC - Larix decidua.

\begin{tabular}{|c|c|c|c|}
\hline Stand & $187 c 20$ & 188 & $805 j 13$ \\
\hline GPS coordinates & $\begin{array}{l}48^{\circ} 58^{\prime} 6.31^{\prime \prime} \mathrm{N} \\
18^{\circ} 39^{\prime} 15.40^{\prime \prime} \mathrm{E}\end{array}$ & $\begin{array}{l}48^{\circ} 58^{\prime} 5.55^{\prime \prime} \mathrm{N} \\
18^{\circ} 39^{\prime} 24.47^{\prime \prime} \mathrm{E}\end{array}$ & $\begin{array}{l}49^{\circ} 49^{\prime} 59.69^{\prime \prime} \mathrm{N} \\
14^{\circ} 46^{\prime} 25.71^{\prime \prime} \mathrm{E}\end{array}$ \\
\hline Area $\left(m^{2}\right)$ & 58,900 & 125,200 & 27,200 \\
\hline Soil & rendzina & rendzina & cambisol \\
\hline Slope $(\%)$ & 40 & 30 & 12 \\
\hline Tree species & SM $60 \%$, B0 $40 \%$ & SM $90 \%$, B0 10\% & SM $95 \%$, SC $3 \%$, BO $2 \%$ \\
\hline Average stem volume $\left(\mathrm{m}^{3}\right)$ & SM 0.07, B0 0.04 & SM 0.07, BO 0.04 & $\begin{array}{c}\text { SM } 0.95, \text { SC } 1.90 \\
\text { B0 } 1.76\end{array}$ \\
\hline Age & 30 & 30 & 121 \\
\hline Total harvest $\left(\mathrm{m}^{3}\right)$ & 90 & 190 & 892 \\
\hline Type of harvest & thinning & thinning & Clear cut \\
\hline Exposition & SW & $S$ & - \\
\hline Season of harvest & June-July 2013 & June-July 2013 & August 2013 \\
\hline Machines & $\begin{array}{l}\text { Harvester NEUSSON } \\
132 \text { HVT (tracked) } \\
\text { Forwarder NOVOTNÝ } \\
\text { (wheeled) }\end{array}$ & $\begin{array}{l}\text { Harvester NEUSSON } \\
132 \text { HVT (tracked) } \\
\text { Forwarder NOVOTNÝ } \\
\text { (wheeled) }\end{array}$ & $\begin{array}{c}\text { Harvester PONSSE Ergo } \\
\text { (wheeled) } \\
\text { Forwarder PONSSE } \\
\text { Buffalo (wheeled) }\end{array}$ \\
\hline $\begin{array}{l}\text { Share of skid trails covered } \\
\text { with harvesting debris }\end{array}$ & $33 \%$ & $67 \%$ & $55 \%$ \\
\hline $\begin{array}{l}\text { Average height of the pile of } \\
\text { the harvesting debris on the } \\
\text { skid trail }(\mathrm{cm})\end{array}$ & $\begin{array}{c}\text { rut }-9 \\
\text { centre }-33\end{array}$ & $\begin{array}{c}\text { rut - } 11.6 \\
\text { centre }-30.9\end{array}$ & $\begin{array}{c}\text { rut }-11 \\
\text { centre }-23.3\end{array}$ \\
\hline
\end{tabular}

Table 2. Technical specifications of the impedance probes used during research.

\begin{tabular}{|c|c|}
\hline Characteristic & Specifications \\
\hline Type & ML3 \\
\hline Range & Accuracy figures apply from 0.05 to $0.6 \mathrm{~m}^{3} \mathrm{~m}^{-3}$. Full range from 0.0 to $1.0 \mathrm{~m}^{3} \mathrm{~m}^{-3}$ \\
\hline Accuracy & $\begin{array}{l} \pm 0.01 \mathrm{~m}^{3} \mathrm{~m}^{-3}, 0 \text { to } 40{ }^{\circ} \mathrm{C} \pm 0.02 \mathrm{~m}^{3} \mathrm{~m}^{-3}, 40 \text { to } 70^{\circ} \mathrm{C} \text { after calibration to a specific } \\
\text { soil type }\end{array}$ \\
\hline Soil salinity errors & $\begin{array}{l}0.0 \text { to } 250 \mathrm{mS} \mathrm{m}^{-1},<-0.0001 \mathrm{~m}^{3} \mathrm{~m}^{-3} \text { change per mS m} \mathrm{m}^{-1}, 250 \text { to } 2,000 \mathrm{mS} \mathrm{m}^{-1}, \text { no } \\
\text { significant change }\end{array}$ \\
\hline $\begin{array}{l}\text { Soil sampling } \\
\text { volume }\end{array}$ & $\begin{array}{l}>95 \% \text { influence within cylinder of } 4.0 \mathrm{~cm} \text { diam., } 6 \mathrm{~cm} \text { long, (approximately } 75 \mathrm{~cm}^{3} \text { ), } \\
\text { surrounding central rod }\end{array}$ \\
\hline Environment & $\begin{array}{l}\text { Will withstand burial in wide ranging soil types or water for long periods without } \\
\text { malfunction or corrosion (IP68 to } 5 \mathrm{~m} \text { ) }\end{array}$ \\
\hline Stabilization time & 1 to $5 \mathrm{sec}$. from power-up, depending on accuracy required \\
\hline Response time & Less than $0.5 \mathrm{sec}$. to $99 \%$ of change \\
\hline Duty cycle & $100 \%$ (continuous operation possible) \\
\hline
\end{tabular}


(volume $100 \mathrm{~cm}^{3}$, length $50 \mathrm{~mm}$, outer diameter $53 \mathrm{~mm}$ ), cylinder holder and a carrying case. Before taking the sample the cylinder was inserted into the holder. The cylinder was then pressed into the soil, until it was filled with soil. The gravimetric samples were not taken from the same place where the impedance measurements were carried out, as this would affect the gravimetric sampling measurements. The soil samples were taken near the place of the soil impedance measurements (approximately 5-10 cm away from the place of the soil impedance measurement). Subsequently the cylinders were hermetically sealed and taken to the laboratory for further analyses. Raw samples were weighed on laboratory scales with resolution of $10 \mathrm{mg}$, placed into a laboratory drier, and dried for 24 hours at $105^{\circ} \mathrm{C}$. After drying the samples were weighed again and from the weight difference of the samples the moisture content was calculated. The following formula was used (Hraško et al., 1962):

$\theta=\frac{a-b}{V} \times 100$

$\theta(\%)$ - volumetric moisture content, $a(\mathrm{~g})$ weight of raw soil sample, $b(\mathrm{~g})$ - weight of dried soil sample, $V\left(\mathrm{~cm}^{3}\right)$ - volume of the sampling cylinder.

We used both methods at every measurement location.

The gravimetric sampling and impedance measurements were carried out in sample plots established across the stand based on the requirements of statistical sampling and the variability of the natural conditions in the stands (Scheer, 2010). In general the area of the sample plots was $10 \%$ of the total area of the stand in stands up to $50,000 \mathrm{~m}^{2}$. In stands larger than 50,000 $\mathrm{m}^{2}$, the area of the sample plots was $5 \%$ of the total area of the stand (Lukáč, 2005). The sample plots were located on skid trails disturbed by the machine traffic. The dimensions of the sample plots were $20 \times 20 \mathrm{~m}$. The sample plots were selected primarily because besides soil disturbance, we also studied the damage to the remaining stand (not the subject of this paper).

The following equation was used to calculate the sample size (Šmelko, 2007):

$i \%=\frac{n \times p}{P}$

$i \%$ - sampling intensity, $n \times p$ - dimensions of all sample plots $\left(\mathrm{m}^{2}\right), P$ - dimensions of the stand $\left(\mathrm{m}^{2}\right)$.

The following equation was used to determine the spacing between the individual sample plots (Šmelko, 2007):

$s=100 \times \sqrt{\frac{P}{n}}$

$s$ - spacing between sample plots, $P$ - stand area $\left(\mathrm{m}^{2}\right), n$ - number of sample plots.

The measurement locations for soil disturbance were positioned on two opposing sides of each plot, and were located on the skid trail. The measurement locations were: (i) in the ruts of the skid trail (one side); (ii) the centre of the skid trail (between the individual ruts); (iii) the undisturbed stand (control measurements). This allowed collection of two sets of material on one sample plot and a total of six samples for each method. In stand no. 805j13 a clear cut was carried out, rendering establishing sample plots unnecessary. In this stand the moisture content was measured on measurement sites positioned on the skid trails with spacing of $5 \mathrm{~m}$ (Schürger, 2012). The measurement locations were the same as for the sample plot method, i.e. ruts, centre and undisturbed stand. The total number of measurements was 138 for each method.

The STATISTICA 10 program was used to process the data. Univariate analysis of variance (Oneway ANOVA) analysis served to evaluate the differences between results provided by both methods. The number of samples was the same for both measurement methods, thus we used the Tukey's HSD test to evaluate, which data groups contributed to rejecting the hypothesis of 
equality of moisture contents provided by the gravimetric sampling and impedance methods. Linear regression and correlation analysis was used to identify whether there is a relationship between the results obtained from gravimetric sampling and the soil impedance methods.

\section{Results}

We conducted statistical analyses on the data from individual stands. ANOVA proved the size of differences of data provided by individual methods was statistically significant in stands no. 187c20 and 805j13 (Table 3). In stand no. 187c20, the soil moisture content measured by the gravimetric sampling was higher than moisture content measured through the impedance method (Figure 1). In the ruts, both methods showed increased moisture content. The greatest difference between data from individual methods was $20.23 \%$ in the rut location (Figure 2). In stand no. $805 j 13$, the size of difference of soil moisture content observed by individual methods was smaller. Due to the smaller size of

Table 3. Results of ANOVA for each stand. Statistically significant values are marked with bold typeface. $S S$ - Sum of squares, DF - degrees of freedom, MSS - Mean squares, $F-F$ statistic, $p-p$ value.

\begin{tabular}{llrrrrc}
\hline Stand no. & Effect & \multicolumn{1}{c}{$S S$} & $D F$ & \multicolumn{1}{c}{ MSS } & \multicolumn{1}{c}{$F$} & $p$ \\
\hline $187 \mathrm{c} 20$ & Absolute term & $\mathbf{3 8 , 8 8 2 . 8 4}$ & $\mathbf{1}$ & $\mathbf{3 8 , 8 8 2 . 8 4}$ & $\mathbf{8 1 8 . 4 0}$ & $\mathbf{0 . 0 0}$ \\
& Moisture content & $\mathbf{1 , 1 2 9 . 6 3}$ & $\mathbf{1}$ & $\mathbf{1 , 1 2 9 . 6 3}$ & $\mathbf{2 3 . 7 8}$ & $\mathbf{0 . 0 0}$ \\
& Error & $3,325.76$ & 70 & 47.51 & & \\
\cline { 2 - 6 } 188 & Absolute term & $\mathbf{1 3 0 , 0 8 8 . 3}$ & $\mathbf{1}$ & $\mathbf{1 3 0 , 0 8 8 . 3}$ & $\mathbf{9 1 2 . 4 9}$ & $\mathbf{0 . 0 0}$ \\
& Moisture content & $\mathbf{1 , 9 9 6 . 1}$ & $\mathbf{1}$ & $\mathbf{1 , 9 9 6 . 1}$ & $\mathbf{1 4 . 0 0}$ & $\mathbf{0 . 0 0}$ \\
& Error & $20,244.1$ & 142 & 142.6 & & \\
\cline { 2 - 7 } $805 j 13$ & Absolute term & $\mathbf{1 9 , 7 0 7 . 3 1}$ & $\mathbf{1}$ & $\mathbf{1 9 , 7 0 7 . 3 1}$ & $\mathbf{7 7 4 . 8 1}$ & $\mathbf{0 . 0 0}$ \\
& Moisture content & 62.83 & 1 & 62.83 & 2.47 & 0.12 \\
& Error & $1,475.23$ & 58 & 25.44 & & \\
\hline
\end{tabular}

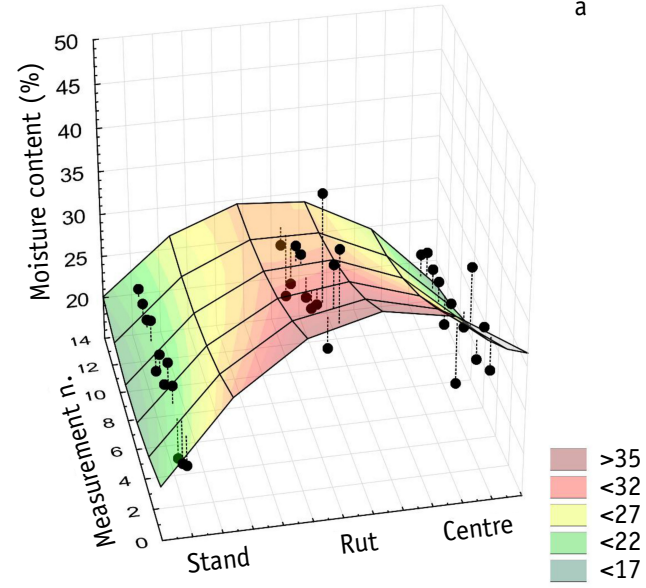

b

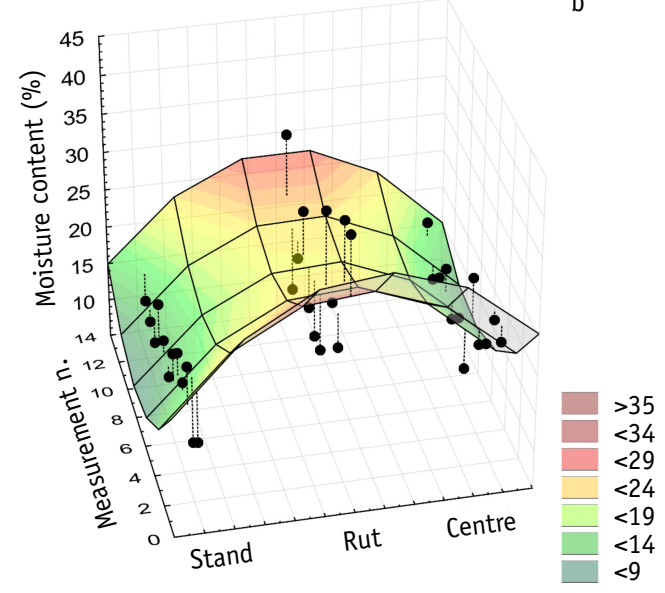

Figure 1. 3D scatter plots showing the development of moisture content measured through gravimetric sampling (a) and the impedance method (b) in the undisturbed stand, rut, and centre of the skid trail locations in stand no. 187c20. Quadratic trend line added to illustrate the overall differences between gravimetric sampling and impedance method. 


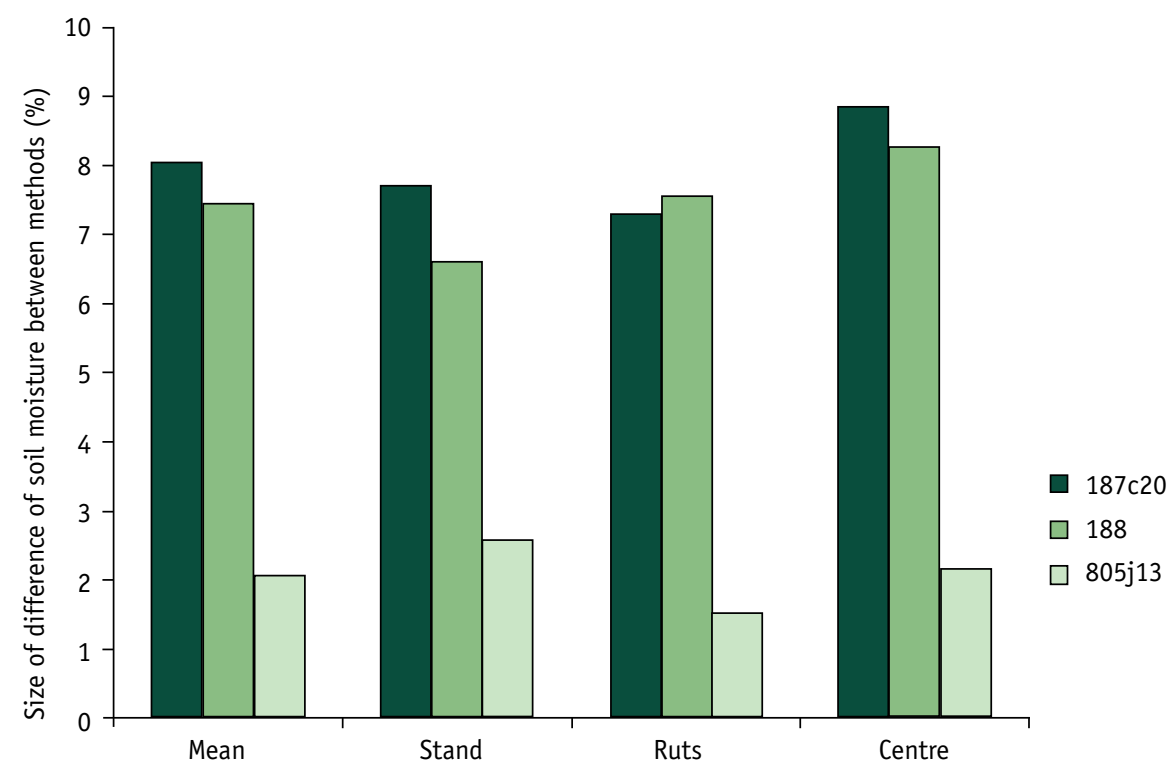

Figure 2. The size of differences between impedance method and gravimetric sampling method in all of the stands.

the statistical sample, the effect of variability of data was more influential (Figure 3). The maximal difference between data from individual methods was $8.10 \%$ in the ruts of the skid trail (Figure 2). In stand no. 188, the differences of data provided by individual methods were statistically insignificant (Figure 4). The maximal moisture content (54.90\%) and moisture content difference were measured in the ruts of the skid trail (Figure 2). Detailed results obtained by using gravimetric sampling and the impedance methods are shown in Table 4.

The mean moisture content recorded with the impedance probes was $22.48 \%$ (Standard deviation - SD: 10.74\%). The mean moisture content provided by the gravimetric sampling method was $28.88 \%$ (SD: $10.88 \%$ ). In the undisturbed stand, the mean moisture content measured with the impedance probes was $16.76 \%$ and $22.77 \%$ when measured by gravimetric sampling. In the ruts, the average moisture content recorded with the impedance probes was $30.28 \%$ and $36.44 \%$ when calculated from the soil samples. In the centre of the skid trail, the mean moisture content recorded by the impedance probes was $20.41 \%$. The moisture content calculated from the soil samples was $27.44 \%$.

The difference between results provided by individual methods was $7.43 \%$ overall, which was caused mainly by combining the dissimilar data from individual stands. When looking at the size of differences of data provided by the gravimetric sampling method and the impedance method, greater differences show in stands no. 187c20 $(8.57 \%)$ and $188(8.53 \%)$ and smaller differences show in stand no. 805j13 (3.39\%). The smaller size of differences of data provided by the compared methods in stand no. 805j13 could be caused by the height of pile of harvesting debris on the skid trail.

Overall the lower moisture content was observed on data from the impedance method than was observed when using the gravimetric sampling method, with the exception of data from ruts. The soil impedance data also showed greater variability, with $S D$ almost twice as high as $S D$ of the gravimetric data.

The results of the Tukey's HSD test showed that in stand no. 187c20 all relevant 

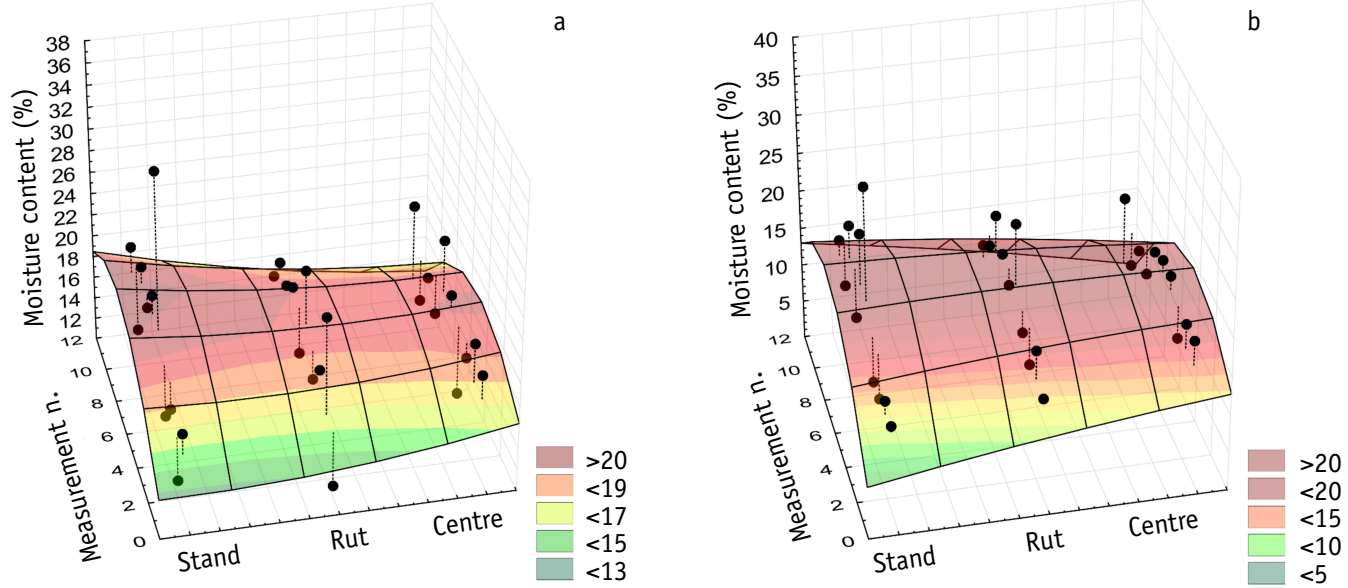

Figure 3. 3D scatter plots showing the development of moisture content measured through gravimetric sampling (a) and the impedance method (b) in the undisturbed stand, rut, and centre of the skid trail locations in stand no. 805j13. Quadratic trend line added to illustrate the overall differences between gravimetric sampling and impedance method.
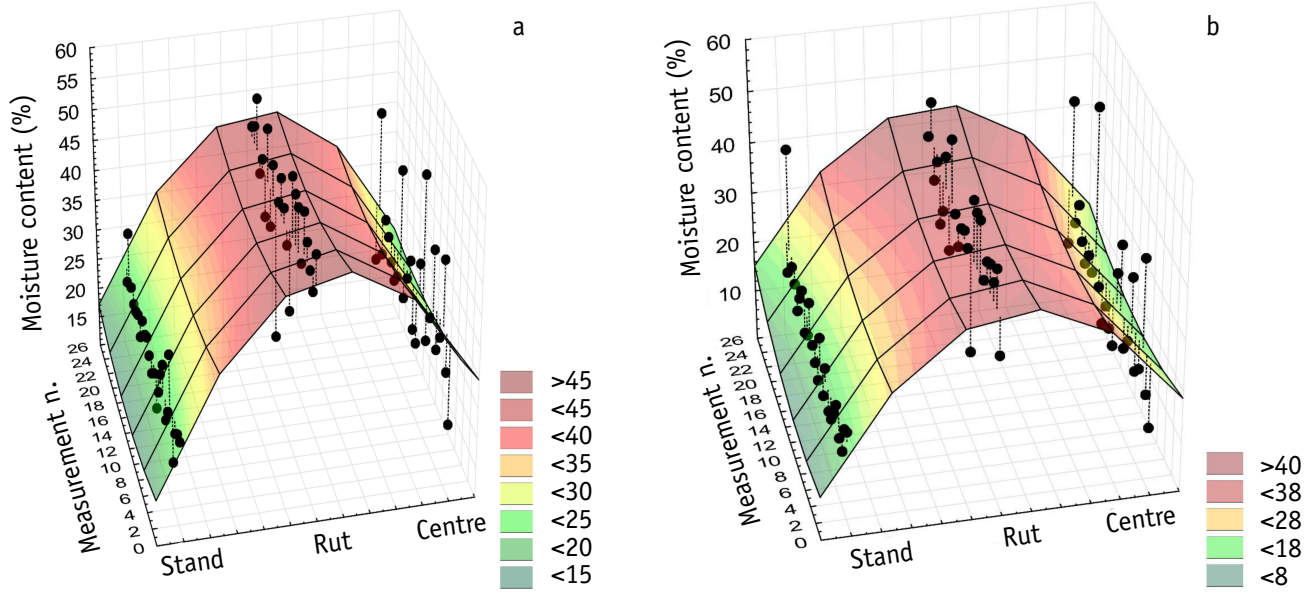

Figure 4. 3D scatter plots showing the development of moisture content measured through gravimetric sampling (a) and the impedance method (b) in the undisturbed stand, rut, and centre of the skid trail locations in stand no. 188. Quadratic trend line added to illustrate the overall differences between gravimetric sampling and impedance method.

Table 4. Moisture content (\%) in individual stands and particular measurement places. SD - standard deviation (\%), GS - gravimetric sampling method, IM - impedance method.

\begin{tabular}{|c|c|c|c|c|c|c|c|c|c|}
\hline & \multicolumn{2}{|c|}{ Total } & \multicolumn{2}{|c|}{ Stand } & \multicolumn{2}{|c|}{ Ruts } & \multicolumn{2}{|c|}{ Centre } \\
\hline & & Mean & $S D$ & Mean & $S D$ & Mean & $S D$ & Mean & $S D$ \\
\hline \multirow[t]{2}{*}{$187 c 20$} & GS & 27.20 & 6.23 & 22.95 & 2.36 & 32.33 & 7.12 & 26.32 & 4.24 \\
\hline & $I M$ & 19.28 & 7.50 & 15.25 & 3.17 & 25.08 & 9.49 & 17.50 & 4.56 \\
\hline \multirow[t]{2}{*}{188} & $G S$ & 33.78 & 11.58 & 23.90 & 3.77 & 45.85 & 7.78 & 31.60 & 8.98 \\
\hline & $I M$ & 26.33 & 12.29 & 17.29 & 6.25 & 38.29 & 7.98 & 23.42 & 10.95 \\
\hline \multirow[t]{2}{*}{$805 j 13$} & GS & 19.15 & 4.79 & 19.83 & 6.57 & 18.79 & 4.21 & 18.81 & 3.52 \\
\hline & $I M$ & 17.10 & 5.28 & 17.30 & 7.82 & 17.30 & 4.40 & 16.70 & 3.02 \\
\hline
\end{tabular}


pairs of data were significantly different. In all measurement places (undisturbed stand, rut, and centre of the skid trail), the impedance method provided significantly different results than gravimetric sampling. In stand no. 805j13, we found that only measurements in ruts showed significant differences. In stand no. 188, none of the relevant pairs of data were significantly different. Table 5 shows the results of the Tukey's test.

Linear regression and correlation analysis performed on data from all forest stands combined showed a strong relationship between the results obtained from gravimetric sampling and soil impedance methods (R: $0.85 ; R^{2}: 0.72 ; p<0.00$ ).

\section{Discussion}

Cosh et al. (2005) found that the impedance probes calibrated according to the manufacturer's instructions have an error of $\pm 5 \%$ of the volumetric soil moisture. Field specific calibration reduced the error to less than 4\%. Gaskin \& Miller (1996) and Miller et al. (1997) reported similar results. Their results regarding the error of impedance probes correspond with our findings. Although the coefficient of correlation was high, and the relationship between results obtained from both methods correlate strongly, the size of differences between results provided by both methods in this study was about $7.43 \%$ on average (Figure 5). The impedance method provided significantly different results at least in conditions mentioned in this paper (soil type rendzina and cambisol). General calibration procedure provided by the manufacturer of the impedance probes used in this study did not refine the accuracy of the impedance probes sufficiently and other ways of calibrating the probes would be necessary, if the results were to be accurate. The Literature on this topic is sparse, but there are authors who developed site-specific calibration protocols, some of which are applicable for use in the field. Most of the calibration protocols are based on calibration through regression with the data from numerous gravimetric samples (Tsegaye et al., 2004; Hornbuckle \& England, 2004). The calibration procedure can be also adapted from calibration of capacitance probes (Morgan et al., 1999; Geesing et al., 2004; Kelleners et al., 2004) and Time-domain reflectometry (TDR) probes (Walker et al., 2004). Kaleita et al. (2005) recommends calibrating the impedance probes on at least 20 soil samples.

\section{Conclusions}

This paper is based on comparison of two most used methods for determining the moisture content of soils - gravimetric sampling and impedance methods. The study was conducted in three forest stands, from which soil samples were taken into Kopecky cylinders and soil impedance was measured through Theta probes attached to the Eijkelkamp Penetrologger penetrometer. The data was then statistically evaluated through the ANOVA analysis and the Tukey's HSD test. The results of the analyses showed that statistically significant differences between individual methods appear in two out of three stands considered. In one stand, the differences between data provided by the individual methods were not significant. The calibration procedure provided by the producer of the Theta probes did not sufficiently refine the accuracy of the impedance method in some soil types. That is the reason why the impedance probes have to be calibrated for specific conditions of individual stands.

During the study, variability of soil conditions was not considered. In stand no. $805 j 13$, the presence of harvesting debris was not considered.

Acknowledgements. This paper was elaborated as a part of scientific grant project VEGA - 1/0678/14 "Optimization of technological, technical, economic and biological principles of energy dendromass production". 


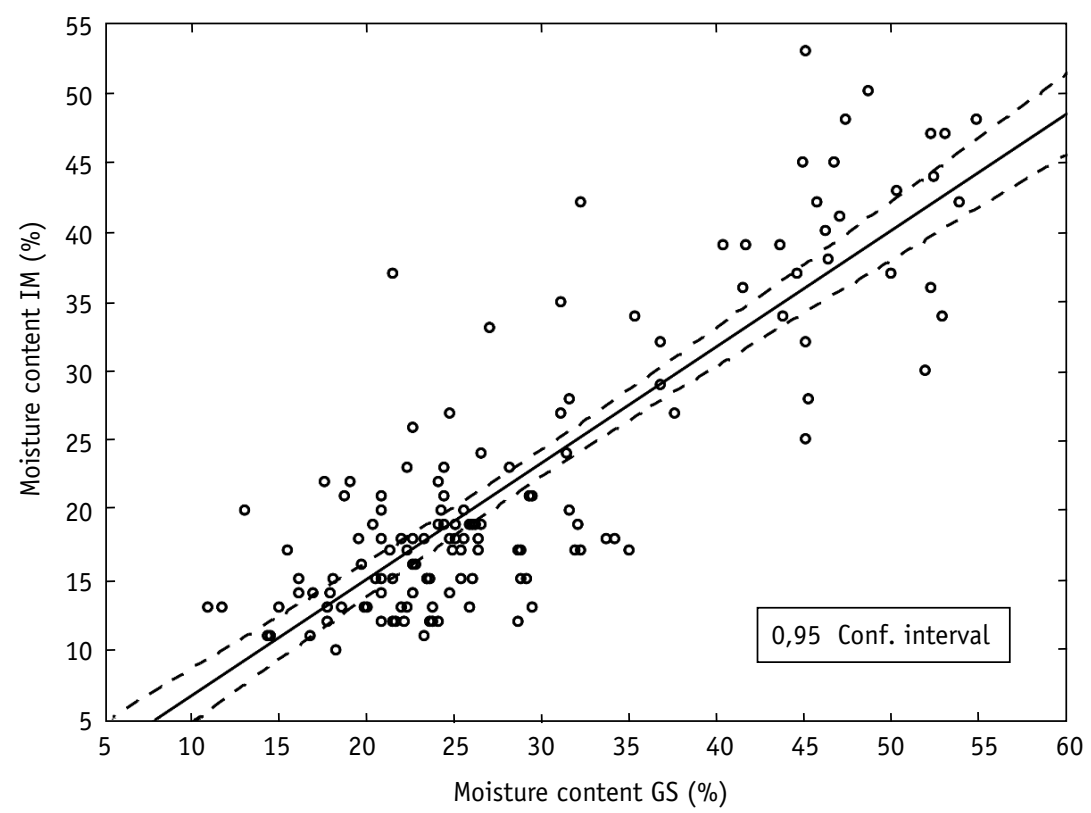

Figure 5. Scatterplot depicting a linear relationship between measurements by gravimetric and impedance method in all stands combined; IM - impedance method, GS - gravimetric sampling.

Table 5. Results of the Tukey's HSD tests carried out on data from individual stands. Statistically significant values are marked with bold typeface, GS - gravimetric sampling method, IM - impedance method, $S$ - the undisturbed stand, $R$ - rut, $C$ - the centre of the skid trail.

\begin{tabular}{|c|c|c|c|c|c|c|c|}
\hline Stand no. & Factor & GSS & GS $R$ & GS C & $I M S$ & $I M R$ & $I M C$ \\
\hline \multirow[t]{6}{*}{$187 c 20$} & GS S & & 0.002070 & 0.698423 & 0.018401 & 0.940937 & 0.193052 \\
\hline & GS $R$ & 0.002070 & & 0.116130 & 0.000130 & 0.031403 & 0.000130 \\
\hline & GS C & 0.698423 & 0.116130 & & 0.000274 & 0.994793 & 0.004391 \\
\hline & IM S & 0.018401 & 0.000130 & 0.000274 & & 0.001131 & 0.926926 \\
\hline & $I M R$ & 0.940937 & 0.031403 & 0.994793 & 0.001131 & & 0.021161 \\
\hline & IM C & 0.193052 & 0.000130 & 0.004391 & 0.926926 & 0.021161 & \\
\hline \multirow[t]{6}{*}{188} & GS S & & 0.000020 & 0.010143 & 0.045490 & 0.000020 & 0.999944 \\
\hline & $G S R$ & 0.000020 & & 0.000020 & 0.000020 & 0.012561 & 0.000020 \\
\hline & GS C & 0.010143 & 0.000020 & & 0.000020 & 0.040619 & 0.004829 \\
\hline & IM S & 0.045490 & 0.000020 & 0.000020 & & 0.000020 & 0.080641 \\
\hline & IM $R$ & 0.000020 & 0.012561 & 0.040619 & 0.000020 & & 0.000020 \\
\hline & $I M C$ & 0.999944 & 0.000020 & 0.004829 & 0.080641 & 0.000020 & \\
\hline \multirow[t]{6}{*}{$805 j 13$} & GS S & & 0.997682 & 0.997887 & 0.884267 & 0.884267 & 0.758746 \\
\hline & GS $R$ & 0.997682 & & 1.000000 & 0.987352 & 0.987352 & 0.945200 \\
\hline & GS C & 0.997887 & 1.000000 & & 0.986642 & 0.986642 & 0.943249 \\
\hline & IM S & 0.884267 & 0.987352 & 0.986642 & & 1.000000 & 0.999851 \\
\hline & $I M R$ & 0.884267 & 0.987352 & 0.986642 & 1.000000 & & 0.999851 \\
\hline & IM C & 0.758746 & 0.945200 & 0.943249 & 0.999851 & 0.999851 & \\
\hline
\end{tabular}




\section{References}

Anderson, H., Boddington, D., van Rees, H. 1992. The long-term effects of sawlog-only harvesting on some soil physical and chemical properties in East Gippsland. Melbourne, Department of Conservation and Environment, Victoria, Australia. 29 pp.

Cosh, M.H., Jackson, T.J., Bindlish, R., Famiglietti, J.S., Dongryeol, R. 2005. Calibration of an impedance probe for estimation of surface soil water content over large regions. - Journal of Hydrology, 311(1-4), 49-58.

Eijkelkamp Agrisearch Equipment. 2013. User Manual for the ML3 ThetaProbe [WWW document]. URL http://pkd.eijkelkamp.com/Portals /2/ Eijkelkamp/Files/Manuals/M1-14260702e\%20 Thetaprobe.pdf (Accessed 30 April 2014).

Fares, A., Abbas, F., Maria, D., Mair, A. 2011. Improved calibration functions of three capacitance probes for the measurement of soil moisture in tropical soils. - Sensors (Basel, Switzerland), 11, 4858-4874. DOI: $10.3390 /$ s110504858

Farrish, K.W. 1990. Effects of soil loss on emergence and growth of loblolly pine. - Journal of Soil and Water Conservation, 45(3), 415-417.

Ferenčík, M. 2011a. Damages caused by the cut-tolength technology on beech stand after salvage felling. - COYOUS 2011: Proceedings of the $4^{\text {th }}$ International Conference of Young Scientists, Czech Republic, Apr. 2011. Prague, 157-166.

Ferenčík, M. 2011b. Damage of forest soil after logging forest harvesting with the use of the HSM 805 wheeled skidder. - Prace Komisji Nauk Rolniczych, Leśnych i Weterynaryjnych, 15(1), 79-85.

Flinn, D.W., Bales, J.L. 1990. Value adding and silvicultural systems program (Vic.) Value adding and silvicultural systems program: report by the expert group and an associated sub-committee to the program manager on study specifications and research priorities for the value adding utilisation system study. Melbourne, Flinn. D.W.

Gaskin, G.J., Miller, J.D. 1996. Measurement of soil water content using a simplified impedance measuring technique. - Journal of Agricultural Engineering Research, 63(2), 153-160.

Geesing, D., Bachmaier, M., Schmidhalter, U. 2004. Field calibration of a capacitance soil water probe in heterogeneous fields. - Soil Research, 42(3), 289-299.

Gerasimov, Y., Katarov, V. 2010. Effect of Bogie Track and Slash Reinforcement on Sinkage and Soil Compaction in Soft Terrains. - Croatian Journal of Forest Engineering, 31(1), 35-45.

Hornbuckle, B.K., England, A.W. 2004. Radiometric sensitivity to soil moisture at $1.4 \mathrm{GHz}$ through a corn crop at maximum biomass. Water Resources Research, 40(10), W10204.
Hraško, J., Červenka, L., Facek Z., Komár, J., Němeček, J., Pospíšil, F., Sirový, V. 1962. Soil analyses. (Rozbory pôd). Bratislava, Slovenské vydavatel'stvo pôdohospodárskej literatúry. 342 pp. (In Slovakian).

Kaleita, A.L., Heitman, J.L., Logsdon, S.D. 2005. Field calibration of the Theta probe for Des Moines lobe soils. - Applied Engineering in Agriculture, 21(5), 865-870.

Kelleners, T.J., Soppe, R.W.O., Ayars, J.E., Skaggs, T.H. 2004. Calibration of capacitance probe sensors in a saline silty clay soil. - Soil Science Society of America Journal, 68(3), 770-778.

Lukáč, T. 2005. Multioperational machines in forestry. (Viacoperačné stroje $\mathrm{v}$ lesnom hospodárstve). Zvolen, Technická univerzita vo Zvolene. 137 pp. (In Slovakian).

Miller, J.D., Gaskin, G.J., Andreson, H.A. 1997. From drought to flood: catchment responses revealed using novel soil water probes. - Hydrological Processes, 11(5), 533-541.

Morgan, K.T., Parsons, L.R., Wheaton, T.A., Pitts, D.J., Obreza, T.A. 1999. Field calibration of a capacitance water content probe in fine sand soils. - Soil Science Society of America Journal, 63(4), 987-989.

Nemestothy, N. 2009. Soil under pressure - is soil protection and forest harvesting compatible?). (Boden unter Druck-sind Bodenschutz und Holzernte vereinbar?). - Büro Führungskräfte der Wirtschaft Praxis, 19, 9-13. (In German).

Poršinsky, T., Sraka, M., Stankič, I. 2006. Comparison of two approaches to soil strength classifications. Croatian Journal of Forest Engineering, 27(1), 17-26.

Rab, M.A. 1994. Changes in physical properties of a soil associated with forest harvesting of Eucalyptus regnans forest in Southeastern Australia. - Forest Ecolology and Management, 70, 215-229.

Rab, M.A., Bradshaw, F.J., Campbell, R.G., Murphy, S. 2005. Review of factors affecting disturbance, compaction and trafficability of soils with particular reference to timber harvesting in the forests of SouthWest Western Australia. Kensington, Department of Conservation and Land Management. $146 \mathrm{pp}$.

Roth, C.H., Malicki, M.A., Plagge R. 1992. Empirical evaluation of the relationship between soil dielectric constant and volumetric water content as the basis for calibrating soil moisture measurements by TDR Soil Science, 43, 1-13.

Ryan, D., Huntington, T.G., Martin, W. 1992. Redistribution of soil nitrogen, carbon and organic matter by mechanical disturbance during wholetree harvesting in northern hardwoods. - Forest Ecology and Management, 49, 87-90.

Scheer, L'. 2010. Biometry. (Biometria). Zvolen, Vydavatel'stvo Technickej univerzity vo Zvolene. 334 pp. (In Slovakian). 
Schürger, J. 2012. Soil disturbance caused by skidders working in cableway terrains. (Zhodnotenie negatívneho vplyvu traktorových technológií na pôdu v lanovkových terénoch). Dissertation thesis, Zvolen, 198 pp. (In Slovakian).

Sever, S., Horvat, D. 1981. The impact of selected characteristics of soil on the mobility of vehicles and a proposal of classification of forest terrains. (Utjecej nekih karakteristika tla na prohodnost vozila te prijedlog za njihovo proučavanje kod izrade klasifikacije šumskih terena). - Mechanizacija šumarstva, 6(9-10), 287-299. (In Croatian).

Sklenar, V. 2008. Soil protection and forest harvesting. (Bodenschutz und Holzernte). Erfurt, Ministerium für Landwirtschaft, Naturschutz und UmweltPresse. 27 pp. (In German).

Šmelko, Š. 2007. Dendrometry (Dendrometria). Zvolen, Vydavatel'stvo Technickej univerzity vo Zvolene. 401 pp. (In Slovakian).

Šušnjar, M., Horvat, D., Šešelj, J. 2006. Soil compaction in timber skidding in winter conditions. - Croatian Journal of Forest Engineering, 27(1), 3-15.
Tsegaye, T.D., Tadesse, W., Coleman, T.L., Jackson, T.J., Tewolde, H. 2004. Calibration and modification of impedance probe for near surface soil moisture measurements. - Canadian Journal of Soil Science, 84(2), 237-243.

Uhl, E., Ohrner, G., Matthies, D., Kremer, H., Wolf, B. 2003. Recommendations for using wheeled and crawler-type machines. (Einsatzempfehlungen für Rad - und Raupenfahrwerke). - Langfristige Waldökosystem-Forschung aktuell, 39, 11-14. (In German).

Walker, J.P., Willgoose, G.R., Kalma, J.D. 2004. Insitu measurement of soil moisture: a comparison of techniques. - Journal of Hydrology, 293(1), 85-99.

Whalley, W.R. 1993. Considerations on the use of timedomain reflectometry (TDR) for measuring soil moisture content. - Journal of Soil Science, 44, 1-9.

White, I., Knight, J.H., Zegelin, S.J., Topp, G.C. 1994. Comments on 'Considerations on the use of timedomain reflectometry (TDR) for measuring soil water content' by W R Whalley. - Journal of Soil Science, 45, 503-508. 